\title{
Proceeding
}

Supplementary Issue: Autumn Conferences of Sports Science. Costa Blanca Sports Science Events, 18-19 December 2020. Alicante, Spain.

\section{Disability and inclusion: Swimming to overcome social barriers}

\author{
PASQUALE IMPARATO 14 , ITALO SANNICANDRO², RICCARDO IZZO³, SARA ALIBERTI'1 , TIZIANA \\ D'ISANTO4
}

${ }^{1}$ Department of Human, Philosophical and Education Sciences, University of Salerno, Italy

${ }^{2}$ Department of Humanistic Studies, University of Foggia, Italy

${ }^{3}$ Department of Biological Sciences, University Carlo Bo of Urbino, Italy

4 University of Salerno, Italy

\begin{abstract}
Nowadays all people can and must practice physical activity and engage themselves in various sports specialties. Among the various sports, swimming is ideal in all situations where the weight of the body is a problem, such as in cases of lower limbs disability (amputations, paralysis, etc.). The objective of this study is to investigate if disabled and not-disabled athletes can derive performance benefits and if it is possible to reduce the gap between the competition times between athletes, through a single, performance and training activity. The sample is made up of 12 athletes, including 6 disabled, belonging to the S2 category, and 6 notdisabled athletes skilled in the back. After an anamnesis and a careful initial valuation, it was proposed to all the athletes to do the HIIT method (for 4 weeks), Tabata method (for 4 weeks), and Pilates one (for 8 weeks). Moreover, to the disabled athletes were given physiotherapy sessions to increase joint ROM for 8 weeks. The aim is to promote social inclusion for disabled athletes, often marginalized by the group, to break down those who are the pillars of difference.

Keywords: Swimming; Unique performance; Training activity; Inclusion; Disability; Well-being.
\end{abstract}

\section{Cite this article as:}

Imparato, P., Sannicandro, I., Izzo, R., Aliberti, S., \& D'Isanto, T. (2021). Disability and inclusion: Swimming to overcome social barriers. Journal of Human Sport and Exercise, 16(2proc), S688-S696. doi:https://doi.org/10.14198/jhse.2021.16.Proc2.54

Corresponding author. Department of Human, Philosophical and Education Sciences, University of Salerno, Italy. https://orcid.org/0000-0002-8222-4459

E-mail: p.imparato6@studenti.unisa.it

Abstract submitted to: Autumn Conferences of Sports Science. Costa Blanca Sports Science Events, 18-19 December 2020. Alicante, Spain.

JOURNAL OF HUMAN SPORT \& EXERCISE ISSN 1988-5202

(c) Faculty of Education. University of Alicante doi:10.14198/jhse.2021.16.Proc2.54 


\section{INTRODUCTION}

Swimming is a cyclical sport with high quantitative base such as energetic cost and power (Altavilla, 2020, 2019, Raiola \& Altavilla, 2020, Raiola et al., 2020) than qualitative base (Raiola, 2017, 20215ab, 2013) and it is characterized by continuous repetitions of stereotyped cycles of movements carried out in a stable environment, such as the stroke. Generally, and from point of the view, the swimming has not socio-educative value such as team sport (Altavilla et al, 2020, D'Elia, et al, 2020, Di Domenico et al.,2020, Raiola et al, $2020 \mathrm{abc}$ ) but the epistemology of exercise and sport sciences include (Gaetano, 2012ab, Raiola, 2020ab, 2019ab, Raiola et al, 2018) especially about the adapted physical activity (D'Isanto 2020abc, 2019abc, 2016). These fundamentals of exercise and sport sciences are the significant elements for degrees academic course to develop the inclusion sport (D'Elia, 2020, 2019, D'Elia, D'Isanto, 2019). These starts point needs to deep the assessing aspects (D'Isanto et al., 2019, Sgro et al., 2019, 2018, 2017, 2015ab) inclusion aspects of sport between disabled and not disabled people. In this way, not only is the general pattern of movement relatively constant, but also the average power of the load or the speed of an athlete moving at a distance; the exception is in the short distances during which the speed of movement (Esposito \& Raiola, 2020) changes significantly. Quickly the athlete must become aware of the muscular commitments it entails, especially the timing and the intensity with which the most important muscle groups are put into action. This image is essential to build the rhythmic base of the movement (Izzo et al., 2020) which perhaps represents the most important element of the structure itself. On Earth, to counteract gravity force involves a constant waste of energy (D'Elia, 2020), which in water is largely abolished, on the other hand, propulsion in water involves much higher caloric cost due to the greater resistance (Altavilla et al., 2019) of water than air. Minor alterations in the swimming technique are responsible for significant differences in propulsive efficiency and the evolution of various techniques has led to the combination of different positions of the forearm and arm tend to favour the movements of the upper limb in the antero- rear, useful for propulsion (Mazzeo et al., 2018). The techniques to minimize the action-reaction) forces (D'Elia et al., 2020) acting on the vertical plane used by not-disable swimmers are not equally applicable to disable swimmer due to structural modifications and joint and dynamic body differences (Di Domenico et al., 2019). For this reason, each different handicap requires an individualized technical project, which considers the anatomical and functional characteristics (Sannicandro et al., 2020) of each individual athlete. In the specific gesture of disable athlete, we can find:

a. Reduced ROM: incomplete stroke with semi-flexed elbow with lateral dispersion of thrust energy;

b. Unwanted lateral movements: difficulty to maintain swimming direction, especially in asymmetrical injuries;

c. Stroke of the lower limbs: the stroke of the lower limbs may be too wide and / or occur with excessive knee flexion.

After completing a pool, to start the next one, the athlete performs a particular type of inversion of the direction of travel, called a turn or overturn, pushing against the edge of the pool with a relaxation of the lower limbs. A disabled swimmer can be more or less affected to lower limbs according to his pathology and consequently they perform a flip that is less efficient from the propulsive point of view. These are the elements that characterize the performance gap (Raiola, 2020) between the times in the pool of the two types of athletes. In reference to world records, disabled swimmer times are 3 times greater than those of a not-disabled swimmer. The goal of this study is to analyse the qualitative and quantitative differences (D'lsanto et al., 2019; Esposito et al., 2019) of two types of athletes regarding the specific gesture in the pool; after which we will work to minimize these differences. 


\section{METHOD AND MATERIALS}

The sample consisted of 12 athletes, 6 athletes with disabilities and 6 non-disabled athletes with an average age of 23 years, who were given an 8-week training program. The program consists of 4 weeks of HIIT training and the other 4 weeks of Tabata training. During the 8 weeks, an attempt was made to increase joint ROM by having physiotherapy sessions for the 6 disabled athletes, and to have a Pilates workout for all the athletes examined. Height $(\mathrm{cm})$, Weight $(\mathrm{Kg})$, Years, $\mathrm{VO}_{2 \mathrm{Max}}$ and joint $\mathrm{ROM}$ were analysed as parameters and then the times in the pool of the 12 athletes were taken. To analyse data, Microsoft Excel software was used: linear regressions in order to observe the differences found between the pool times of the two types of athletes, multiple regression to extrapolate which of the variables depended more on the times and finally the two-tailed T-Test with equal variance both on times and on the number of strokes pre and post-training to highlight the possible differences induced by training.

\section{RESULTS}

The results show that although times have improved in all athletes, especially those with disabilities, the difference is still evident. The stroke variable is the one that has the greatest influence in pool times compared to the other variables (weight, $\mathrm{VO}_{2 \mathrm{Max}}$, years).

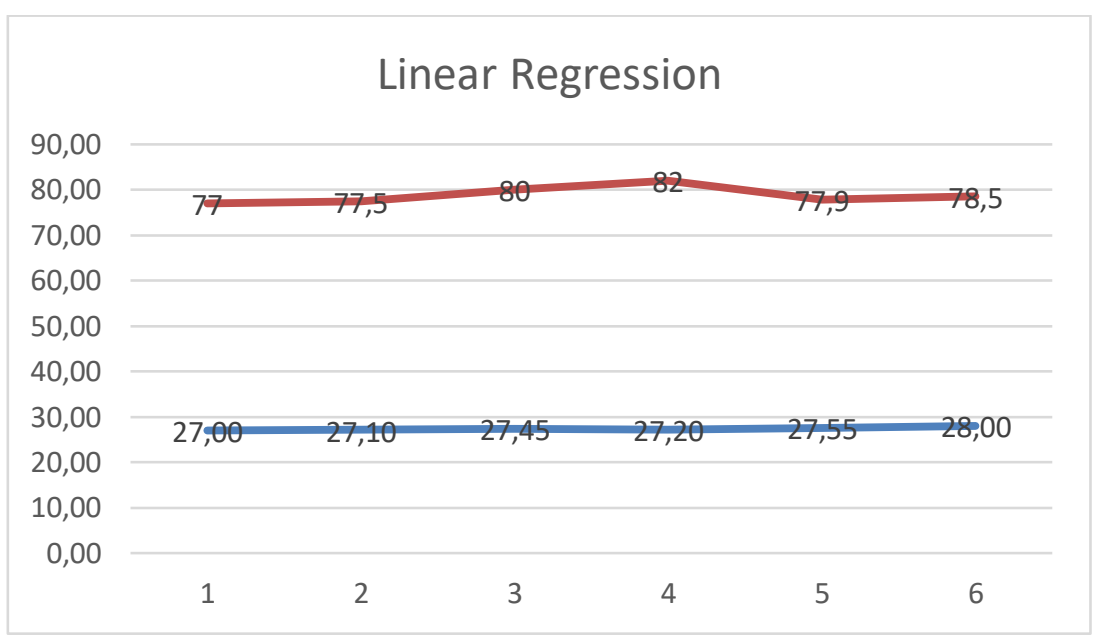

Note: The orange line indicates the times of the athletes belonging to the S2 category, the blue line to the not-disabled athletes.

Figure 1. Graph relating to the times (pre-training) of the two types of athletes.

Table 1. Pre-training table of multiple regression.

\begin{tabular}{ll}
\hline & Coefficients \\
\hline Intercept & -32.80432251 \\
Years Variable & 0.131724281 \\
Weight Variable & -0.003647286 \\
Strokes Variable & 0.72070067 \\
VO $_{2 \text { Max Variable }}$ & 0.470751504 \\
\hline
\end{tabular}

Note: The most influential variable is that relating to strokes. 


\section{8 weeks training}

Table 2. HIIT Training, 30:30.

\section{Week 1-4 HIIT}

30 " swim to $90 \% \mathrm{VO}_{2 \mathrm{Max}}$

Repeat 10 times

30 " swim to $70 \% \mathrm{VO}_{2 \mathrm{Max}}$

Table 3. Tabata Training, 20:10.

\section{Week 5-8 Tabata}

$20 "$ al $120 \% \mathrm{VO}_{2 \mathrm{Max}}$

10" stop

Repeat until the times remain constant

\section{Linear Regression}

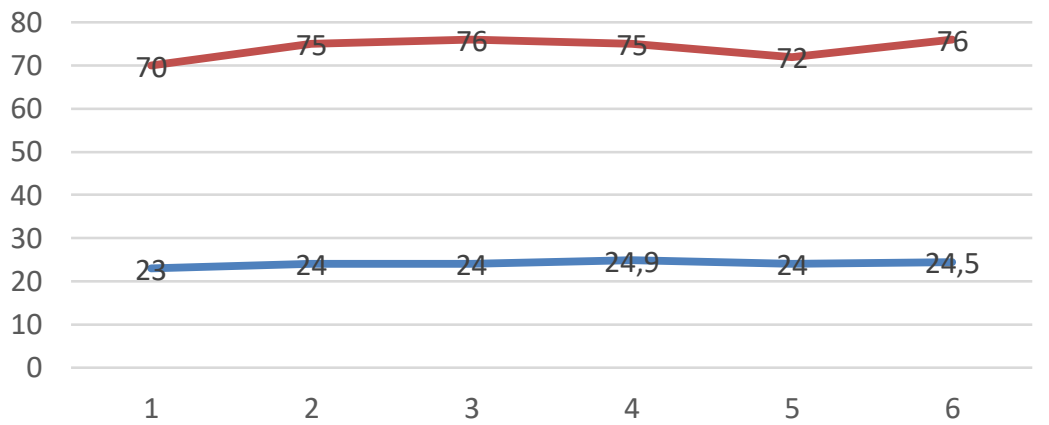

Note: There is still a substantial gap. Blue line highlights the times of not-disabled athletes, the orange line indicates the times of athletes belonging to $S 2$ category.

Figure 2. Time chart post workout.

Table 4. Post-workout table of multiple regression.

\begin{tabular}{ll}
\hline & Coefficients \\
\hline Intercept & 17.44101719 \\
Years Variable & -0.248337433 \\
Weight Variable & -0.226547456 \\
Strokes Variable & 0.691640495 \\
VO $_{2 M a x}$ Variable & 0.140896887 \\
\hline
\end{tabular}
Note: It appears that the stroke variable is still the determining variable.

Table 5. Two Tails Test-T with same variance to times.

\begin{tabular}{lll}
\hline & Variable 1 & Variable 2 \\
\hline Mean & 53.1 & 50.17083333 \\
Variance & 723.1222727 & 590.5202083 \\
Remarks & 12 & 12 \\
Total variance & 656.8212405 & \\
Hypothesized difference for means & 0 & \\
Gdl & 22 & \\
Stat t & 0.279960083 & \\
$p(T<=t)$ one tail & .391061793 &
\end{tabular}




\begin{tabular}{ll}
\hline Critic $t$ one tail & 1.717144374 \\
$p(T<=t)$ two tails & .782123587 \\
Critic $t$ two tails & 2.073873068 \\
\hline
\end{tabular}

Note: The difference does not influence in positive way.

Table 6. Two Tails Test-T with same variance to strokes.

\begin{tabular}{lll}
\hline & Variable 1 & Variable 2 \\
\hline Mean & 65.08333333 & 60.91666667 \\
Variance & 1424.083333 & 1213.537879 \\
Remarks & 12 & 12 \\
Total Variance & 1318.810606 & \\
Hypothesized difference for means & 0 & \\
Gdl & 22 & \\
Stat $t$ & 0.281043256 & \\
$p(T<=t)$ one tail & .390651737 & \\
Critic one tail & 1.717144374 & \\
$p(T<=t)$ two tails & .781303473 & \\
Critic $t$ two tails & 2.073873068 & \\
\hline
\end{tabular}

Note: Difference does not influence in positive way.

\section{DISCUSSION}

Based on a first observation, linear regression allows us to the difference between the time of the pool of disabled and not-disabled swimmers (Figure 1). By analysing the coefficients of the variables in multiple regression, it is possible to note that the stroke variable has a greater influence on the increase in the gap between the times in the pool of the two types of athletes (Table 1) than the others (weight, $\mathrm{VO}_{2 \mathrm{Max}}$, years). To the subjects examined were offered an 8-week training which included 2 different training methods. In the first 4 weeks athletes did HIIT workout in which alternated 30 " of strokes at $90 \%$ of $\mathrm{VO}_{2 \mathrm{Max}}$ and 30 " of strokes at $70 \%$ of $\mathrm{VO}_{2 \mathrm{Max}}$ repeated 10 times (Table 2). By training with a HIIT method, athletes can gain a better physical condition and a higher athletic capacity (Altavilla et al., 2020), moreover, HIIT workouts are advantageous for an improvement in the aerobic (Pastore et al., 2019; Calandro et al., 2020) and anaerobic threshold thanks to the frequent change of pace. The second training cycle, consisting of the other 4 weeks, included a "Tabata" style training in which the athletes swim at $120 \%$ of $\mathrm{VO}_{2 \mathrm{Max}}$ for 20 " followed by 10 " of complete inactivity (recovery) to be repeated until the distance covered in the 20 " remained unchanged (Table 3). Tabata is a training method that requires constant transitions from anaerobic to aerobic metabolism based on the variation in intensity (Invernizzi et al., 2020), to allow for regular recovery in order to maintain anaerobic performance (Gaetano \& Rago, 2014; D'Elia et al., 2020) over time. These two types of training work on the aerobic and anaerobic thresholds of athletes. During the 8 weeks, an attempt was made to increase joint ROM by having physiotherapy sessions for the 6 disabled athletes, and to have a Pilates workout for all the athletes examined. Pilates Method, also called Pilates, is a training system developed at the beginning of the twentieth century by Joseph Pilates, which involves an exercise program that focuses on postural muscles (Aliberti et al., 2020), that help keep the body balanced, essential to support the spine. Pilates exercises raise awareness of breathing (Raiola et al., 2020a) and spinal alignment by strengthening the muscles of the deep plane of the trunk. It turns out to be an excellent complementary training for highlevel athletes (Rago et al., 2017). At the end of the 8 weeks, the pool times of the 12 athletes were examined again and the same tests were performed again with the addition of the t-test. The linear regression shows how the gap between the times of the two types of athletes is still substantial (Figure 2). Once again, multiple 
regression (Table 4) shows the stroke variable has the greatest impact on times. Tables 5 and 6 relating to the t-tests of times and strokes show that the differences between times in pool are still considerable despite a reduction in times and gaps.

\section{CONCLUSION}

The study show that it was not possible to eliminate the performance gap between the two types of athletes in 8 weeks of training, although the performance was improved in all the subjects involved. Disabled athletes reported that they were more motivated to train and compare with their not-disabled colleagues, so much so that the improvements they achieved were better than the results of not-disabled colleagues. Therefore, a common performance and training activity for disabled and not-disabled people can bring improvements not only from the performance point of view, but also from the psychosocial point of view (Cascone et al., 2020). Although in recent years the competitions in which disabled and not-disabled athletes compete together are increasing, the difference in times is still too evident an element. For greater gratification and a greater inclusive perspective (D'Elia et al., 2020) we could go and look for "strategies" such as, for example, the use of small "counterweights" for not-disabled athletes in order to equalize the times in the pool. In this way disabled athletes can feel more gratified thanks to greater inclusion.

\section{REFERENCES}

Aliberti, S., Invernizzi, P.L., Scurati, R., D'Isanto, T. (2020) Posture and skeletal muscle disorders of the neck due to the use of smartphones Journal of Human Sport and Exercise, 15, pp. S586-S598. https://doi.org/10.14198//hse.2020.15.Proc3.11

Altavilla, G. (2020) Energetic cost in the different running conditions in team sport for the educational teaching method, Sport Science, 14 (1), pp. 17-20.

Altavilla, G. (2019) Monitoring training to adequate the teaching method in training: An interpretative concepts, Journal of Physical Education and Sport, 19, art. no. 258, pp. 1763-1766.

Altavilla, G., D'Isanto, T., \& D'Elia, F. (2020). The educational value of rules in basketball. Journal of Human Sport and Exercise, 15(4proc), S1195-S1203. https://doi.org/10.14198/ihse.2020.15.Proc4.21

Altavilla, G., D'elia, F., D'isanto, T., Manna, A. (2019) Tests for the evaluation of the improvement of physical fitness and health at the secondary school, Journal of Physical Education and Sport, 19, art. no. 262, pp. 1784-1787.

Calandro, A., Esposito, G., Altavilla, G. (2020) Intermittent training and improvement of anthropometric parameters and aerobic capacity in youth football Journal of Human Sport and Exercise, 15, pp. S599-S608. https://doi.org/10.14198/ihse.2020.15.Proc3.12

Cascone, C., De Cesare, G.R., D'Elia, F. (2020) Physical education teacher training for disability, Journal of Human Sport and Exercise, 15, pp. S634-S644. https://doi.org/10.14198/ihse.2020.15.Proc3.16

D'Elia, F. (2020) Teachers' perspectives about contents and learning aim of physical education in Italian primary school, Journal of Human Sport and Exercise, 15 (Proc2), pp. S279-S288. https://doi.org/10.14198//hse.2020.15.Proc2.19

D'Elia, F., Di Domenico, F., D'Isanto, T., Altavilla, G., Raiola, G. (2020) From biomechanics to motor learning, Acta Medica Mediterranea, 36 (5), pp. 3073-3078.

D'Elia, F., Rago, V., Ermidis, G., Raiola, G. (2020) Relationship between lower limb asymmetries and functional capacities in women in Basketball: A case study Sport Science, 13 (1), pp. 90-95. 
D'Elia, F., Tortella, P., Sannicandro, I., \& D'Isanto, T. (2020). Design and teaching of physical education for children and youth. Journal of Human Sport and Exercise, 15(4proc), S1527-S1533. https://doi.org/10.14198/ihse.2020.15.Proc4.48

D'Elia, F., Sgrò, F., D'isanto, t. (2020b) The educational value of the rules in volleyball, Journal of Human Sport and Exercise, 15, pp. S628-S633. https://doi.org/10.14198/hhse.2020.15.Proc3.15

D'Elia, F. (2019b) The core curriculum of university training to teach physical education in Italy, Journal of Physical Education and Sport, 19, art. no. 256, pp. 1755-1758

D'Elia, F., Raiola, G. (2019) Sport and Exercise Sciences Degrees in Italy: Comparison Between Online and Traditional Teaching Models, Communications in Computer and Information Science, 1091, pp. 209-216. https://doi.org/10.1007/978-3-030-31284-8_16

D'santo, T., D'Elia, F., Raiola, G., Altavilla, G. (2019) Assessment of sport performance: Theoretical aspects and practical indications, Sport Mont, 17 (1), pp. 79-82. https://doi.org/10.26773/smj.190214

Di Domenico, F., Sannicandro, I., Altavilla, G. (2020) The educational value of the rules in five-a-side football, Journal of Human Sport and Exercise, 15, pp. S645-S655. https://doi.org/10.14198/ihse.2020.15.Proc3.17

Di Domenico, F., D'isanto, T., Raiola, G. (2019) Role of speed and agility in the effectiveness of motor performance, Journal of Physical Education and Sport, 19, art. no. 271, pp. 1836-1842.

D'Isanto, T. (2020a) Sports skills in sitting volleyball between disabled and non-disabled people, Journal of Physical Education and Sport, 20 (3), art. no. 194, pp. 1408-1414.

D'Isanto, T. (2020b) Competencies and skills in exercise and sport sciences program by online education, Sport Science, 13 (1), pp. 95-98.

D'ssanto, T. (2020c) Test and assessment for improvement of the endurance in youth soccer, Journal of Human Sport and Exercise, 15 (Proc2), pp. S200-S205.

D'santo, T. (2019a) State of art and didactics opportunities of physical education teaching in primary school, Journal of Physical Education and Sport, 19, art. no. 257, pp. 1759-1762.

D'ssanto, T. (2019). Effectiveness and influence of some technical fundamentals on the game's quality in football. Journal of Human Sport and Exercise, 14(5proc), S2026-S2030. https://doi.org/10.14198/ihse.2019.14.Proc5.24

D'santo, T. (2019c) Physical and sport education between Italian academic system and European Research Council structure panel, Journal of Human Sport and Exercise, 14, pp. S66-S76. https://doi.org/10.14198/ihse.2019.14.Proc1.08

D'Isanto, T., D'Elia, F., Raiola, G., Altavilla, G. (2019) Assessment of sport performance: Theoretical aspects and practical indications, Sport Mont, 17 (1), pp. 79-82. https://doi.org/10.26773/smj.190214

D'Isanto, T. (2016) Pedagogical value of the body and physical activity in childhood, Sport Science, 9, pp. 13-18.

Esposito, G., Ceruso, R., D'isanto, T. (2019) Evaluation of some quantitative aspects in the young soccer players training process during puberty, Journal of Physical Education and Sport, 19, art. no. 261, pp. 1777-1783.

Esposito, G., Raiola, G. (2020) Monitoring the performance and technique consolidation in youth football players, Trends in Sport Sciences, 27 (2), pp. 93-100.

Gaetano, R., Rago, V. (2014) Preliminary study on effects of hiit-high intensity intermittent training in youth soccer players, Journal of Physical Education and Sport, 14 (2), pp. 148-150.

Gaetano, R. (2012a) Motor learning and didactics into physical education and sport documents in middle school-first cycle of education in Italy, Journal of Physical Education and Sport, 12 (2), pp. 157-163.

Gaetano, R. (2012b) Didactics of volleyball into the educate program for coaches/trainers/technicians of Italian Federation of Volleyball (FIPAV) Journal of Physical Education and Sport, 12 (1), pp. 25-29. 
Invernizzi, P.L., Signorini, G., Colella, D., Raiola, G., Bosio, A., Scurati, R. (2020)Assessing rolling abilities in primary school children: Physical education specialists vs. generalists, International Journal of Environmental Research and Public Health, 17 (23), art. no. 8803, pp. 1-19. https://doi.org/10.3390/ijerph17238803

Izzo, R., Altavilla, G., Cejudo, A., Raiola, G., D'Isanto, T., Giovannelli, M. (2020) Performance improvement in yo-yo intermittent recovery test Level 2 and during official matches: The role of speed endurance training production in Élite football players, Sport Mont, 18 (3), pp. 61-66. https://doi.org/10.26773/smj.201020

Mazzeo, F., Altavilla, G., D'elia, F., Raiola, G. (2018), Development of doping in sports: Overview and analysis, Journal of Physical Education and Sport, 18 (3), pp. 1669-1677.

Pastore, F., Di Domenico, F., Viscione, I., D'elia, F. (2019)Assessment of aerobic resistance in the young soccer player, Journal of Physical Education and Sport, 19, art. no. 290, pp. 1953-1958.

Raiola, G. (2020) Proposal of rearrangement of physical training and sport sciences methodology academic disciplines in italian university body Sport Science, 14 (1), pp. 43-47.

Raiola, G., Aliberti, S., Esposito, G., Altavilla, G., D'Isanto, T., \& D'Elia, F. (2020). How has the Practice of Physical Activity Changed During the COVID-19 Quarantine? A Preliminary Survey. Teoriâ ta Metodika Fìzičnogo Vihovannâ, 20 (4), 242-247. https://doi.org/10.17309/tmfv.2020.4.07

Raiola, G., Altavilla, G. (2020) Testing motor skills, general and special coordinative, in young soccer, $\begin{array}{llll}\text { Journal of Human Sport and Exercise, } 15 \text { (Proc2), pp. S206-S212. } & \end{array}$ https://doi.org/10.14198/ihse.2020.15.Proc2.11

Raiola, G., Domenico, F.D., Isanto, T.D., Altavilla, G., Elia, F.D. (2020a) Biomechanics core, Acta Medica Mediterranea, 36 (5), pp. 3079-3083.

Raiola, G., Invernizzi, P.L., Scurati, R., \& Fattore, S. (2020). The educational value of the rules in handball. Journal of Human Sport and Exercise, 15(4proc), S1214-S1223. https://doi.org/10.14198/ihse.2020.15.Proc4.23

Raiola, G., Esposito, G., Sgrò, F. (2020) The formative value of soccer rules, Journal of Human Sport and Exercise, 15, pp. S656-S663. https://doi.org/10.14198/ihse.2020.15.Proc3.18

Raiola, G. (2020a) Proposal of rearrangement of physical training and sport sciences methodology academic disciplines in italian university body. Sport Science, 14 (1), pp. 43-47.

Raiola, G. (2020b) The Movement and Sport Science in Italy towards the European Research Council, Physical Culture and Sport, Studies and Research, 86 (1), pp. 37-48. https://doi.org/10.2478/pcssr2020-0011

Raiola, G. (2019a)Comparison of exercise and sport sciences epistemology between european research council structure panel and Italian academic system, Sport Science, 12, pp. 112-120.

Raiola, G. (2019b)Survey on exercise and sport sciences in Italy, Journal of Human Sport and Exercise, 14 (Proc4), pp. S1163-S1168. https://doi.org/10.14198/ihse.2019.14.Proc4.81

Raiola, G., D'elia, F., Altavilla, G. (2018) Physical activity and sports sciences between European Research Council and academic disciplines in Italy. Journal of Human Sport and Exercise, 13, pp. S283-S295. https://doi.org/10.14198//jhse.2018.13.Proc2.13

Raiola, G. Motor learning and teaching method(2017) Journal of Physical Education and Sport, 17, art. no. 236, pp. 2239-2243.

Raiola, G. (2015a) Inclusion in sport dance and self perception, Sport Science, 8, pp. 99-102.

Raiola, G. (2015b) Sport skills and mental health, Journal of Human Sport and Exercise, 10 (Specialissue), pp. S369-S376. https://doi.org/10.14198/jhse.2015.10.Proc1.27

Raiola, G. (2015c) Basketball feint and non-verbal communication: Empirical framework, Journal of Human Sport and Exercise, 10 (Specialissue1), pp. 360-368. https://doi.org/10.14198/ihse.2015.10.Proc1.26 
Raiola, G. (2013) Body knowledge and motor skills, Knowledge Cultures, 1 (6), pp. 64-72.

Rago, V., Pizzuto, F., Raiola, G. (2017)Relationship between intermittent endurance capacity and match performance according to the playing position in sub-19 professional male football players: Preliminary results, Journal of Physical Education and Sport, 17 (2), art. no. 103, pp. 688-691.

Sannicandro, I., Cofano, G., Raiola, G., Rosa, R.A., Colella, D. (2020)Analysis of external load in different soccer small-sided games played with external wildcard players, Journal of Physical Education and Sport, 20 (2), art. no. 98, pp. 672-679.

Sgro, F., Quinto, A., Platania, F., Lipoma, M. (2019) Assessing the impact of a physical education project based on games approach on the actual motor competence of primary school children, Journal of Physical Education and Sport, 19, art. no. 111, pp. 781-786.

Sgrò, F., Pignato, S., Lipoma, M. (2018) Assessing the impact of gender and sport practice on students 'performance required in team games, Journal of Physical Education and Sport, 18, art. no. 71, pp. 497-502.

Sgrò, F., Mango, P., Pignato, S., Schembri, R., Licari, D., Lipoma, M. (2017) Assessing Standing Long Jump Developmental Levels Using an Inertial Measurement Unit, Perceptual and Motor Skills, 124 (1), pp. 21-38. https://doi.org/10.1177/0031512516682649

Sgrò, F., Licari, D., Coppola, R., Lipoma, M. (2015a) Assessment of balance abilities in elderly people by means of a clinical test and a low-cost force plate, Kinesiology, 47 (1), pp. 33-43.

Sgrò, F., Nicolosi, S., Schembri, R., Pavone, M., Lipoma, M. (2015b) Assessing vertical jump developmental levels in childhood using a low-cost motion capture approach, Perceptual and Motor Skills, 120 (2), pp. 642-658. https://doi.org/10.2466/10.PMS.120v12x7

\section{(9) $\odot \Theta \Theta$}

This work is licensed under a Attribution-NonCommercial-NoDerivatives 4.0 International (CC BY-NC-ND 4.0). 